\author{
V International Forum on Teacher Education
}

\title{
Interactive Methods for Organizing Pre-Service Teaching Practice
}

\author{
Olga F. Shikhova*(a), Yuri A. Shikhov (b), Yulia V. Krasavina (c), M. Aiman Al \\ Akkad (d) \\ (a), (b), (c), (d) M.T. Kalashnikov Izhevsk State Technical University, Izhevsk, Russia
}

\begin{abstract}
The paper deals with the problem of organizing effective pre-service teaching practice for bachelor's students. Improving the quality of students' practical training is vital and could be based on the use of interactive teaching methods. The paper presents the typology and principles for organizing professional pedagogical internships aimed at students' personal development and preparation for professional world. This problem is considered in the framework of activity-based approach where key elements are individual creativity, self-development and self-actualization acquired through active learning. The paper also reveals the goals and objectives for all types of professional pedagogical training, and provides examples of their implementation. It is shown that pedagogical training during pre-service teaching forms first professional students' experience and reveals a specific nature of educational work.
\end{abstract}

Keywords: professional pedagogical training, educator, interactive methods, pre-service teaching.

\section{(C) 2019 Olga F. Shikhova, Yuri A. Shikhov, Yulia V. Krasavina, M. Aiman Al Akkad}

This is an open access article distributed under the terms of the Creative Commons Attribution License (CC BY 4.0), which permits unrestricted use, distribution, and reproduction in any medium, provided the original author and source are credited.

Published by Kazan Federal University and peer-reviewed under responsibility of IFTE-2019 (V International Forum on Teacher Education) 


\section{Introduction}

Currently, the intensification of students' learning activity is one of the most urgent problems in higher education. Considering this problem, the researchers note that the most constructive way to solve it is to create such psychological and pedagogical educational conditions where a student is an active participant of the educational process and is in a state of cooperation and co-creation with other students and teachers.

In this regard, we consider interactive teaching methods as a promising tool, which potential is currently not fully realized in higher education when organizing students' teaching practice.

It is known that the pre-service teaching practice deals with the main tasks related to the initial stage of students' professional adaptation. Given that the duration of a bachelor's program is rather short, it is the pre-service teaching practice that has the greatest potential in terms of flexible response to new techniques and teaching methods.

This is especially relevant when training future teachers, who due to the integrative nature of their future educational activity should master the content and methods of teaching for several subjects. It is obvious that the form, content and methods for organizing their pre-service teaching practice should be relevant to this task.

At M.T. Kalashnikov Izhevsk State Technical University we use professional pedagogical training as one of the forms for organizing pre-service teaching practice for future vocational educators. Professional pedagogical training is an interactive form for organizing quasi-professional educational activities of students, aimed at mastering their professional skills specified in the professional standard "Teacher".

The training is aimed at developing students' personal qualities vital for their future profession and preparing them for their future professional activities: teaching, project development, organizational and managerial activities. The need to prepare them for doing that is stated in the federal state educational standard for the program 44.03.04 "Vocational Education" (specializing in Electronics, Radio Engineering and Communication). This program is offered by the Pedagogy Department at M.T. Kalashnikov Izhevsk State Technical University.

Based on these types of activities, the following types of professional pedagogical internships are proposed: pedagogical training, project development training, management training and integrative training.

This paper substantiates the need for organizing all types of practice as a way to enhance the students' practical activities through the systematic development of their professional skills.

\section{Literature review}

The analysis of scientific, research and pedagogical literature has shown that when preparing student teachers for their professional activities, social, psychological and pedagogical internships can be successfully used.

The problem of organizing social and psychological training was considered by Vachkov (2004), Gladyshev (2005), Zakharov (1990), Petrovskaya (2007), Sidorenko (2007) and other researchers. These works focus on the intensive group interaction aimed at improving students' communication competence and acquiring self-cognition and self-development skills. These studies reflected the ideas of foreign scientists Buckley \& Caple (2009), Forverg \& Alberg (1984), Fopel (2003) and others who considered training as a means of active group learning. 
The concept of "pedagogical training" in scientific publications is also associated with the organization of social and psychological training: for working teachers - in order to develop their personal professional qualities through specially organized exercises (Gladyshev, 2005; Nikolaeva, 2012; Petrovskaya, 2007; Vachkov, 2004); or for students - in order to personalize their education and ensure its systematic nature, growing academic load and reflexive assessment (Ibragimova, 2007; Teleeva, 1996; Sherbakov, 2000).

For example, Kuznetsova (1998) highlights a special role of training sessions for future teachers. The author notes that the development of students' professional skills and abilities is largely spontaneous, and it is difficult to control and correct in time. Therefore, training presented as a system of special exercises aimed at combining students' efforts, establishing links between the assimilation and application of their knowledge, creating effective interaction and mutual control, contributes to the development and tracking of future educators' teaching methods, and facilitates its correction.

Shcherbakov (2000) considers pedagogical training as a means of developing the ability of future teachers to work in various educational systems. Noting that a significant number of trainee teachers are not ready for self-development and self-education, the author connects the solution of this problem with individualizing the learning during the pedagogical training. Shcherbakov determines the following pedagogical conditions for effective pedagogical training aimed at individualizing students' preparation for the educational work: allowing students to choose from one of three roles (an observer, a participant, or an organizer); subject-to-subject and personality-significant relations of participants in the process of training; choosing forms and methods of organizing participants' activities during the training session based on the current level of their readiness for educational work.

Morozova's study (2003) is also valuable in the context of our research as it shows that the successful professional development of a personality depends on his/her ability to adequately assess himself/herself and his/her professional activity, that is, how a specialist is capable of reflecting on all significant aspects of his/her professionalization.

The author rightly notes that reflexive processes permeate the whole teaching activity, manifesting itself in the situation of direct interaction and in the process of planning and designing educational activity, as well as at the stage of self-analysis and self-assessment.

In order to solve the problem of developing future teachers' reflexive skills, Morozova (2003) suggests that, among other things, students should participate in training sessions aimed at developing social perception, interpersonal and verbal communication skills.

However, despite a wide range of studies on the development of future teachers' professional qualities and the use of various types of trainings for this purpose, insufficient attention is paid to the practical training aspects of students in the period of teaching practice. The problem of consistency in developing students' professional skills in the conditions of differentiated teaching practice aimed at equipping future teachers with an arsenal of modern innovative techniques and methods is understudied.

Thus, the literature review confirms the relevance and practical significance of using interactive methods for organizing students' teaching practice, including the potential of trainings. The description of professional pedagogical training types and principles of their organization contribute to the theoretical ideas of vocational education and especially to the process of developing students' practical skills during the period of practice, including their preparation for the use of various interactive forms, methods and means of training in the future professional and educational activities. 


\section{Methodology}

It is known that an educator teaches students in the vocational education system and prepares them to fulfill their professional functions at work. The diversity of educators' functions, their complexity and versatility imply a future-oriented character of future teachers' training. It is expected that graduates would be highly-qualified versatile professionals.

However, advanced requirements to the quality of educators training imposed by the new stage of scientific, technical and socio-economic development of society, have come into conflict with traditional approaches to the educational process content, including the content of pre-service teaching practice.

The purpose of the study is to organize pre-service teachers' practice through the series of professional and pedagogical training sessions. Training content reflects the integrative nature of their education, represented by a synthesis of the fundamental, psychological, pedagogical and specialization components of the educational process.

The problem under consideration is studied in the framework of activity-based approach. Within the framework of professional-pedagogical training students are not passive "receivers" of information, but active participants in the educational process who learn the specific nature of pedagogical work through their own activities.

Table 1 shows the stages of pre-service teaching practice and types of vocational and pedagogical training associated with them. The experiment was conducted at M.T. Kalashnikov Izhevsk State Technical University. It should be noted that these types of training are also conducted outside the pre-service teaching practice provided by the curriculum, and they are integrated into bachelor students' educational process in accordance with the previously developed curriculum.

As follows from the Table pedagogical training is focused on the development of students' skills in designing the content of educational material, the use of activity-oriented and student-centered learning techniques and the corresponding didactic tools, analysis of their teaching experience, etc. During pedagogical training, students design illustrated textbooks, test assignments, supporting notes and other didactic materials, which are attached to the report on their pre-service teaching practice.

The objectives of the project development training include the development of skills in planning and selecting the content for classes, setting educational and professional goals and objectives, forecasting the results of professional and educational activities, performing creative interdisciplinary projects, including e-projects, etc.

Table 1

Professional and pedagogical training types and tasks during pre-service teaching practice

\begin{tabular}{|c|c|c|}
\hline Training type & Practice stage & Training tasks \\
\hline Pedagogical & $\begin{array}{c}\text { Preparatory } \\
\text { (Pedagogical 1) } \\
(2 \text { term })\end{array}$ & $\begin{array}{c}\text { Acquiring basic knowledge of } \\
\text { professional duties and official documents in } \\
\text { the field of education. } \\
\text { Development } \text { of didactic materials, } \\
\text { analysis of typical professional and } \\
\text { pedagogical situations, mastering educational } \\
\text { techniques and methods }\end{array}$ \\
\hline $\begin{array}{c}\text { Project } \\
\text { development }\end{array}$ & $\begin{array}{c}\text { Developing planning and } \\
\text { (Pedagogical 2) }\end{array}$ & \begin{tabular}{c} 
instructional design skills applied to goals \\
\hline
\end{tabular} \\
\hline
\end{tabular}




\begin{tabular}{|c|c|c|}
\hline & (4 term) & $\begin{array}{r}\text { and objectives, classes content, creative } \\
\text { interdisciplinary projects. } \\
\text { Mastering the techniques of }\end{array}$ \\
$\begin{array}{c}\text { Organization and } \\
\text { management }\end{array}$ & $\begin{array}{c}\text { Basic-2 } \\
\text { (Pedagogical 3) } \\
(6 \text { term) }\end{array}$ & $\begin{array}{c}\text { Developing skills: designing } \\
\text { monitoring and evaluation procedures; } \\
\text { development, analysis and correction } \text { of } \\
\text { educational documentation }\end{array}$ \\
\hline $\begin{array}{c}\text { Integrative } \\
\text { (includes all types of } \\
\text { activities) }\end{array}$ & $\begin{array}{c}\text { Final } \\
\text { (outside teaching } \\
\text { (pre-graduation } \\
\text { practice) }\end{array}$ & $\begin{array}{c}\text { Analysis of specific professional and } \\
\text { pedagogical situations during the practice } \\
\text { period: developing skills of self-esteem, self- } \\
\text { development, self-determination and } \\
\text { ractiction. Teaching classes. }\end{array}$ \\
\hline
\end{tabular}

Organization and management skills training is associated with: the setting and specifying of learning goals, the choice of criteria for assessing their achievement; diagnostics of the quality of students' training and correcting the educational process. The main objective of this type of training is to develop the future teachers' skills to effectively assess their students' achievements. Students acquire necessary knowledge when studying such disciplines as: Introduction to the Educational Quality Studies, Probability Theory in Monitoring Research, Basics of Expertise in Education, and Modern Tools for Evaluating Learning Outcomes. Students get acquainted with the methods of assessing the quality of education and techniques of designing tools for monitoring research.

Integrative training involves performing different types of professional tasks: organizing and teaching classes, analysis of specific professional and pedagogical situations during the pre-service practice and real teaching practice, development of self-assessment and mutual evaluation skills and reflexive abilities. For the latter we used SWOT-analysis (Isaeva \& Shikhova, 2014; Maisak, 2013) which is one of the popular methods of analyzing situations and assessing the resources in organizations, and is increasingly used in educational research nowadays.

Integrative training includes lectures and practical training sessions taught by students themselves using certain educational methods and techniques. It provides the students' direct participation in the educational process. In addition, integrative training involves the repetitive teaching of various forms of classes but with different content material. Considering that the system of vocational education integrates pedagogical and special (in our case, engineering) components, it is planned to consistently include in its structure general technical and natural science courses (Physical Foundations of Modern Technologies, Principles of Modern Technical Devices, etc.), as well as the humanities (Pedagogical Psychology, Rhetoric, Interactive Learning, English for Special Purposes (Gareyev et al., 2018). Thus, future teachers acquire the experience of self-mastering a new subject area and designing methodology for teaching it.

It should be noted that the classes in the framework of professional pedagogical training sessions are taught by trainee students mainly for their group mates. Practice has shown that this allows them not only to freely exchange the initial professional experience, but also to effectively practice certain educational methods and techniques. Given the shortage of study hours allocated to pre-service teaching practice and its regulated discrete nature, it can be argued that conducting integrative training allows students to expand the range of practical activities and gain confidence in teaching classes. 
Thus, all types of trainings are related to the process of mastering pedagogical skills and abilities and are based on the principles of consistency, interactivity, interdisciplinarity and repeatability.

The consistency of the training procedures means their integration into all types and forms of classes for students at university. In the first year, in addition to curricular practical training, training sessions are integrated into such courses as: Pedagogical Psychology, Informatics and Information Technologies in Education, Practical (Industrial) Education, Introduction to the Vocational Education and Physics. Physics is included due to the shortage of teachers of this discipline in the system of secondary vocational education in the Udmurt Republic and the employers' request related to this fact.

The interactive nature of vocational and pedagogical training appears in the targeted interaction between the educational process participants aimed at improving their behavioral and activity patterns using SWOT analysis.

SWOT-analysis (abbreviated Strengths, Weaknesses, Opportunities, Threats), which we use to analyze situations in teaching practice, involves identifying the strengths and weaknesses of students' practical activities, their possible problems and resources available to solve them . It is used for structured description of a situation, where a decision should be made, but no mandatory recommendations and prioritization are provided (Krasavina et al., 2015).

Table 2 presents a fragment of an evaluation sheet filled in by one of the students using SWOT analysis for introduction of the new federal state educational standards in higher education institutions and the quality of the current curriculum taught in Vocational Education program.

Integrative training include professional simulation games, group discussions, brain storming and other interactive events. Such professional simulation games as Technical College, Conference, Educational Board, Job Application and others imitate various aspects of the future teachers' professional and educational activities and social interaction. At the same time, SWOT-analysis allows them to visualize the advantages and disadvantages of different types of behavior of the game participants.

Interdisciplinary nature of pre-service training implies not only a wide range of academic disciplines, but also the mutual transfer of specific ideas, methods and tools from one subject area to another. This teaches students to go outside the usual framework of one academic course and reflects the integrative nature of the modern scientific knowledge and their future professional and educational activities.

As for the repeatability of training procedures, this principle is associated with the developing students' skills in certain educational areas by repeating them in various situations. For example, during a semester every student masters an educational technique or method (problem-based, critical thinking, project-based learning, etc.) and tries it during pre-service teaching practice in lectures and practical classes. At the same time, he/she participates in discussing and evaluating classes taught by other students using other educational methods.

Table 2

SWOT analysis evaluation sheet

\begin{tabular}{|c|c|c|c|c|c|}
\hline $\begin{array}{l}\text { Analyzed } \\
\text { situation }\end{array}$ & Strengths & Weaknesse & Opportuni & & Threats \\
\hline Introducti & Emphasis & General & The & & Low level \\
\hline on of the new & on the educational & wording & variability of the & of & university \\
\hline
\end{tabular}




\begin{tabular}{|c|c|c|c|c|}
\hline $\begin{array}{l}\text { federal state } \\
\text { educational } \\
\text { standards in } \\
\text { higher education } \\
\text { institutions }\end{array}$ & $\begin{array}{l}\text { outcomes, available } \\
\text { base for assessing } \\
\text { the quality of } \\
\text { students and } \\
\text { graduates training. } \\
\text { Reduction } \\
\text { of the list of } \\
\text { submitted } \\
\text { competences and } \\
\text { clearer wording. } \\
\text { Introducti } \\
\text { on of universal } \\
\text { competencies, with } \\
\text { wording that } \\
\text { reflects their } \\
\text { content }\end{array}$ & $\begin{array}{l}\text { competencies, lack } \\
\text { of methodological } \\
\text { materials for } \\
\text { teachers. } \\
\text { No list of } \\
\text { professional } \\
\text { competencies is } \\
\text { provided. }\end{array}$ & $\begin{array}{l}\text { content, providing } \\
\text { a teacher with } \\
\text { relative freedom in } \\
\text { selecting the of } \\
\text { educational content } \\
\text { and the content of } \\
\text { the graduates' } \\
\text { professional } \\
\text { competence }\end{array}$ & $\begin{array}{l}\text { applicants training, } \\
\text { which makes it } \\
\text { difficult to fulfill } \\
\text { the requirements of } \\
\text { the standards }\end{array}$ \\
\hline $\begin{array}{l}\text { Quality of } \\
\text { the } \quad \text { current } \\
\text { curriculum taught } \\
\text { in Vocational } \\
\text { Education } \\
\text { program. }\end{array}$ & $\begin{array}{l} \\
\text { Fundamen } \\
\text { tal nature of } \\
\text { training }\end{array}$ & $\begin{array}{l}\text { Insufficien } \\
\mathrm{t} \text { teaching hours for } \\
\text { such courses as } \\
\text { Pedagogical } \\
\text { Psychology, } \\
\text { Rhetoric. No } \\
\text { courses on conflict } \\
\text { resolution, keeping } \\
\text { business } \\
\text { documentation }\end{array}$ & $\begin{array}{l}\text { A good } \\
\text { list of the courses } \\
\text { in humanities, } \\
\text { natural sciences } \\
\text { and specialized } \\
\text { disciplines, } \\
\text { expanding the } \\
\text { employment } \\
\text { opportunities for } \\
\text { graduates }\end{array}$ & 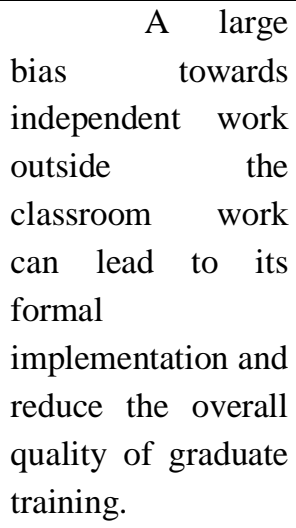 \\
\hline
\end{tabular}

Common criteria and rating scale for assessing classes are set before the beginning of pre-service practice and can be adjusted if necessary. They are applied in the same way to all students without exception.

An example of an evaluation sheet for a lecture taught by a trainee teacher is given below in Table 3.

To define levels and competencies that are developed during pre-service teaching practice, the Expert Group Appraisal method was used. Quantity research was implemented through developing questionnaires for students. Teacher observations and interviewing students together with self-assessment and mutual evaluation also helped us understand the advantages of organizing pre-service practice with interactive games and find solutions for the problems that had arisen. In order to assess the level of professional competence development, a taxonomic model based on Bloom taxonomy was suggested. This model comprises three levels: basic (knowledge, understanding, application), systematic (knowledge, understanding, application, analysis, synthesis) and professional (knowledge, understanding, application, analysis, synthesis, assessment, forecast).

Basic level implies the use of professional concepts and terminology, knowledge of modern 
teaching methods and educational techniques, the ability to plan classes, etc. Systematic level requires an ability to analyze professional and pedagogical situations according to specified criteria, develop and examine testing and assessment materials, etc. Professional level implies mastering instructional design methods, the ability to optimize and introduce new pedagogical techniques, forecast and prevent possible mistakes, etc.

Table 3

Evaluation sheet for lecture

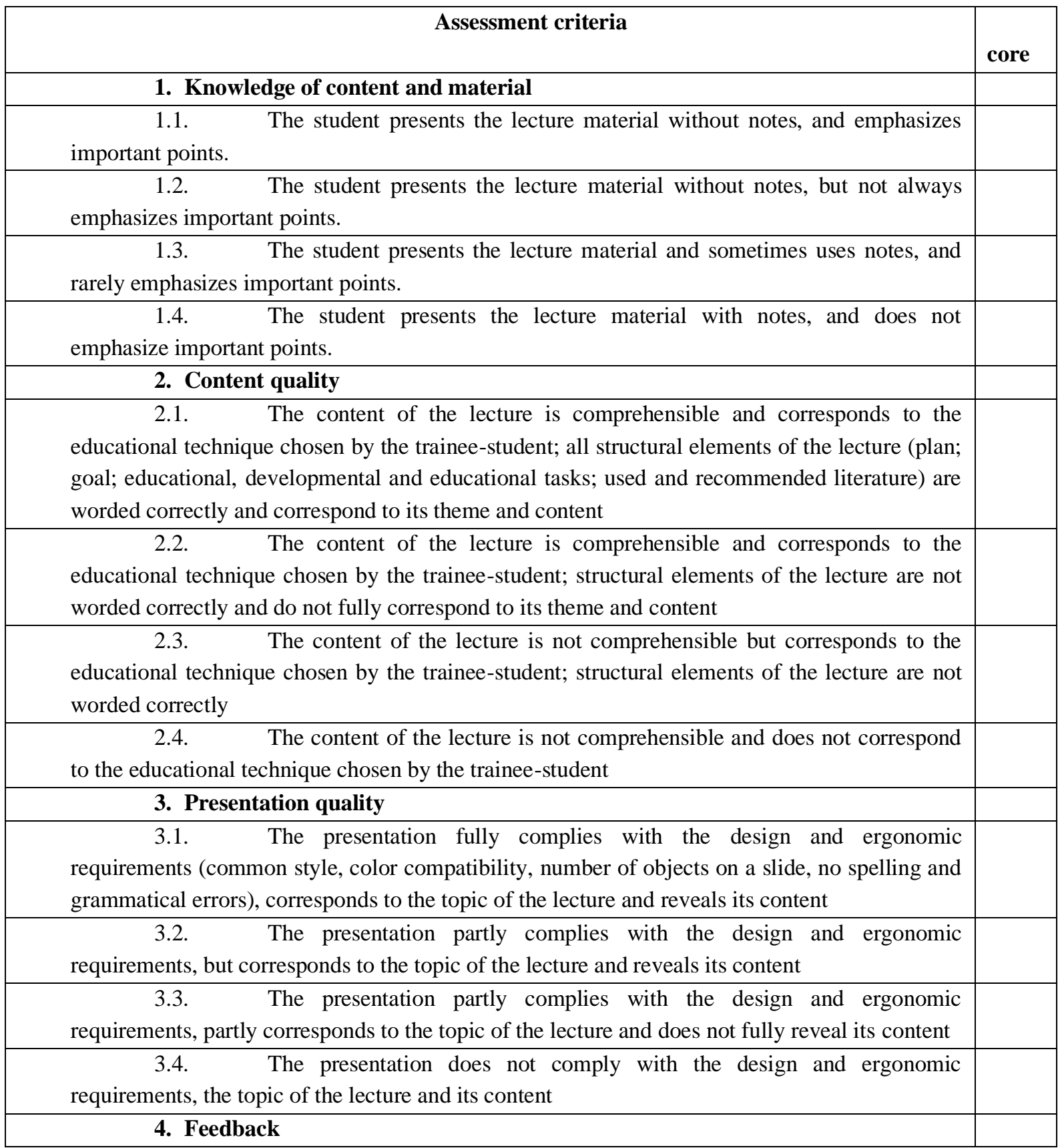




\begin{tabular}{|c|}
\hline $\begin{array}{l}\text { 4.1. Feedback from the audience is efficient and constructive (the trainee } \\
\text { student asks questions, waits for the answers, the audience actively participates in the } \\
\text { discussion, shows interest in the content of the lecture, makes judgments) }\end{array}$ \\
\hline $\begin{array}{l}\text { 4.2. Feedback from the audience is available, but not always efficient and } \\
\text { constructive (audience judgments are not related to the content of the lectures, trainee student } \\
\text { digresses from a topic) }\end{array}$ \\
\hline $\begin{array}{l}\text { 4.3. Feedback is not efficient (audience does not show interest in the content of } \\
\text { the lecture, does not answer the questions correctly, etc.) }\end{array}$ \\
\hline There is no feedback \\
\hline 5. Answering questions \\
\hline $\begin{array}{l}\begin{array}{l}\text { 5.1. } \\
\text { competently. }\end{array} \\
\text { The trainee student answered all the questions posed fully and }\end{array}$ \\
\hline The trainee student answered most questions fully and competently. \\
\hline The trainee student answered half of the questions \\
\hline The trainee student did not answer any question \\
\hline 6. Oracy \\
\hline $\begin{array}{l}\text { 6.1. The trainee student does not make speech mistakes, speaks clearly and } \\
\text { keeps the optimal pace of presentation. }\end{array}$ \\
\hline $\begin{array}{l}\text { 6.2. The trainee student speaks clearly and keeps the optimal pace of } \\
\text { presentation, but makes insignificant speech mistakes (incorrect stress / slips of the tongue / } \\
\text { junk words). }\end{array}$ \\
\hline $\begin{array}{l}\text { 6.3. The trainee student makes speech mistakes (incorrect stress / slips of the } \\
\text { tongue / junk words), does not speak clearly }\end{array}$ \\
\hline $\begin{array}{l}\text { 6.4. The trainee student demonstrates a low level of speech proficiency } \\
\text { (monotony, slurred speech, speech mistakes) }\end{array}$ \\
\hline
\end{tabular}

Rating scale: 17-18: "excellent" score; 14-16: "good" score; 10-13: "satisfactory" score; less

than 10: "poor" score.

\section{Results}

Our experiments in introducing professional and pedagogical training sessions for future vocational educators in 2012 - 2018 showed their interest in this form of pre-service teaching practice. They noted that it is quite effective for the development of students' professional skills and creative abilities, providing them with targeted assistance in resolving specific professional and pedagogical situations which were identified with SWOT- analysis.

The participants were university students enrolled in the Vocational Education bachelor's program (64 students) of first, second, third and final years of study. Results of evaluating professional competence development for students after completing teaching pre-service practice are shown in Fig. 3.

Fig. 3 shows that most of the first year students (83\%) acquired a basic level of professional pedagogic competence. It means that in the first year, a student is developing basic knowledge and understanding of his or her future profession. Later, students developed higher levels of professional competence and that happened due to introducing pre-service teaching practice including pedagogical training sessions aimed at mastering skills of organizing and planning the class, as well as instructional 
design and evaluation skills. Most students described their experience of participating in a training session as a positive, interesting and motivating. However, quantity research about how interactive activities affect students' professional competence development compared to traditional teaching still needs to be done.

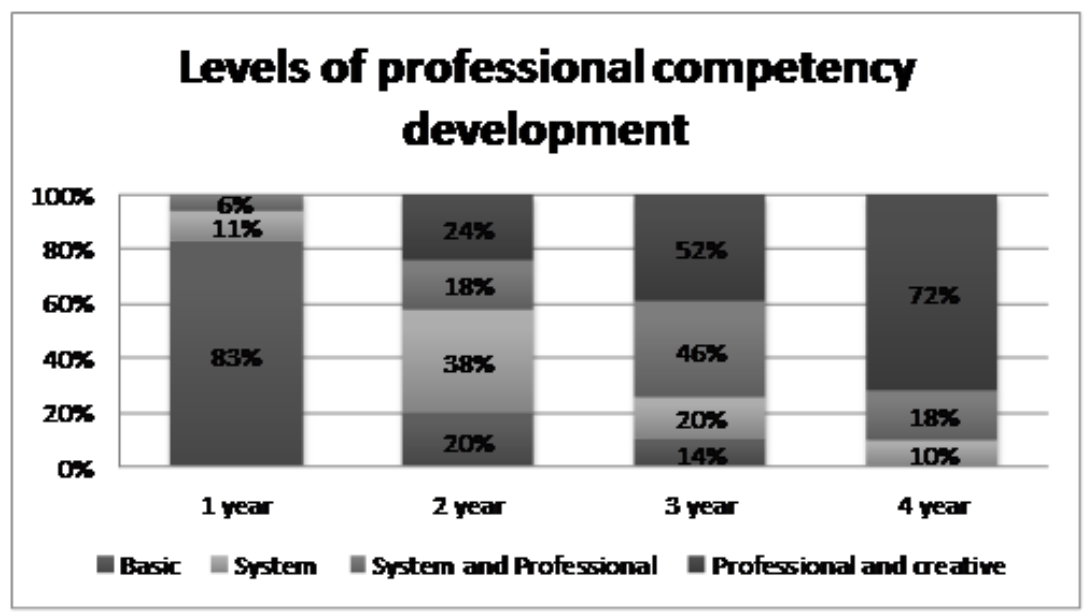

Fig. 3 Results of evaluating professional competence development for 1-4 year Vocational Education students after completing teaching pre-service practice

\section{Discussion}

Analyzing the problems arising during graduates' adaptation to the professional teaching practice in educational institutions of the Udmurt Republic, we revealed a lack of practical training to teach a wide range of related interdisciplinary courses, and use modern teaching methods for this purpose.

Professional and pedagogical training involving interactive pre-service teaching practice is aimed at solving these problems.

Positive experience of integrating professional and pedagogical training into teaching practice revealed several issues that require further reflection and study:

1. Organizational issues. Pre-service teaching practice should address specific nature of integrative training of future vocational educators, which means that students should be able to plan and teach classes in psycho-pedagogical courses, natural science, general and specific professional courses. This requires interaction and coordinated decisions of the relevant departments throughout the entire period of training students at the university. Such extensive and important work cannot be done by one person, so it may be worth taking the necessary management decisions in this regard.

2. External conditions. Currently, the teaching practice is performed in the conditions of permanent reformation of higher and vocational education system. In our opinion, the need to adapt to innovations makes it difficult for students to introduce innovative educational techniques and predict trends in the changing conditions of their future profession.

\section{Conclusion}

The interactive methods for organizing pre-service teaching practice presented in the paper can contribute to effective development of students' professional skills. Presented types of trainings are related to the types of vocational educator activities: education, project development, organizing and management, 
as well as with an integrative activity reflecting the multifunctional nature of the vocational educator work.

The process of organizing professional and pedagogical training is governed by the principles of consistency, interactivity, interdisciplinarity and repeatability. They are implemented through the selection of the pedagogical practice integrative content, the variety of interactive teaching methods used, emphasis on reflexive and evaluative activities of students, and the development of skills in using specific educational techniques when giving lectures and practical classes.

Designing the training procedures from the standpoint of the activity-based approach, we consider that mastering basic skills in teaching will enable students to discover their creativity, avoid stressful situations when applying for a job, and open up prospects for their professional development and selfrealization.

Interviews with graduates, teachers and employers, as well as the research results show that the pre-service teaching practice organized with the use of interactive teaching methods better prepares them for future educational activities, and forms a positive initial professional experience.

The work was supported by grant No. 44.06.01/18ШЮА “Acquiring, development and diagnostics of students' competencies in the system of continuous education" supported by M.T. Kalashnikov Izhevsk State Technical University

\section{References}

Buckley, R., \& Caple, J. (2009). The Theory \& Practice of Training. London: Kogan Page.

Fopel, K. (2003). Technology of conducting training. Theory and practice. Moscow: Genezis.

Forverg, M., \& Alberg, T. (1984). Characteristics of social and psychological behavior training. Psihologicheskij zhurnal, 4, 57-64.

Gareyev, A., Shikhova, O., Shikhov, Yu., \& Krasavina, Yu. (2018). Blogging as a Tool for Organizing Students' Independent Work. Astra Salvensis, 2, 211-224.

Gladyshev, S. A. (2005). How to behave during the training session. Education and Career, 35, 70-77.

Ibragimova, E. V. (2007). Training as pedagogical support for personal self-development of university students. PhD Thesis, Orenburg, Russia.

Isaeva, T.A., \& Shikhova, O.F. (2014). Training as a form of organization of teaching internship. Education and Science, 9(118), 98-112.

Krasavina, Y., Isayeva, T., Shikhova, O., Shikhov, Yu., \& Zhuykova, O. (2015). Recent Trends in Training Vocational Educators in Russia. Paper presented at the 2nd International Multidisciplinary Scientific Conference on Social Sciences and Arts (SGEM 2015).

Kuznetsova, M. E. (1998). The training component as the basis for the development of the educational methodology of future teacher. $\mathrm{PhD}$ Thesis, Tobolsk, Russia.

Maisak, O. S. (2013). SWOT-analysis: object, factors, strategies. The problem of finding relationships between factors. Caspian magazine: management and high technology, 1(21), 151-157.

Morozova, T. A. (2003). Pedagogical reflection as the basis for the professional development of the future teacher. PhD Thesis, Tula, Russia.

Nikolaeva, M. A. (2012). Active learning as a condition for the formation of students' professional competence based on an integrative approach. In Innovative activity in the education system (pp. 81-114). 
Petrovskaya, L. A. (2007). Communication - competence - training. Moscow: Smysl.

Sherbakov, A. V. (2000). Pedagogical training in the individualization of preparing students for educational work in school. $\mathrm{PhD}$ Thesis, Chelyabinsk, Russia.

Sidorenko, E. V. (2007). Technology for creating training. From conception to result. St. Petersburg: Rech.

Teleeva, E. V. (1996) Complex training sessions as a means of educating pedagogical observation in future teachers. PhD Thesis, Ekaterinburg, Russia.

Vachkov, I. V. (2004). Windows to the world of training: methodological foundations of the subjective approach to group work. St. Petersburg: Rech.

Zaharov, V. P., \& Hryashchev, N. Yu. (1990). Social and psychological training. Leningrad; LGU. 